http://dx.doi.org/10.18778/1509-877X.2018.03.02

Jan Sarnowski, LL.M*

Paweł Selera, LL.M**

Anna Bartosiak ${ }^{* *}$

\title{
STAŁE MIEJSCE PROWADZENIA DZIAŁALNOŚCI GOSPODARCZEJ NA GRUNCIE NIEMIECKIEGO PODATKU VAT I NIEMIECKIEJ PRAKTYKI PODATKOWEJ ${ }^{1}$
}

\begin{abstract}
Streszczenie. Celem opracowania jest analiza koncepcji stałego miejsca prowadzenia działalności gospodarczej na gruncie niemieckiej ustawy o VAT oraz wykładni tego pojęcia dokonywanej przez niemieckie sądy finansowe i organy podatkowe. Niemieckie sądy finansowe, dokonując oceny kryteriów pozwalających na przyjęcie istnienia stałego miejsca prowadzenia działalności gospodarczej za punkt wyjścia, słusznie przyjmują Rozporządzenie 282/2011 oraz orzecznictwo TSUE. Niemniej jednak w niektórych przypadkach sądownictwo dopuszcza występowanie stałego miejsca prowadzenia działalności gospodarczej na terytorium Niemiec nawet wówczas, jeśli podatnik korzysta z cudzego personelu albo nie dysponuje żadnym zapleczem personalnym. W opinii autorów jest to wykładnia zbyt daleko idąca, nieznajdująca uzasadnienia ani na gruncie prawa unijnego, ani orzecznictwa TSUE. Słowa kluczowe: stałe miejsce prowadzenia działalności gospodarczej, wystarczająca stałość, odpowiednia struktura w zakresie zaplecza personalnego i technicznego, VAT
\end{abstract}

* LL.M., Podsekretarz Stanu w Ministerstwie Finansów, e-mail: jan.sarnowski@ mf.gov.pl

** Doktor nauk prawnych, LL.M., doradca podatkowy, Dyrektor Departamentu Podatku od Towarów i Usług w Ministerstwie Finansów, e-mail: pawel.selera@mf.gov.pl

*** Ekspert w Departamencie Analiz Podatkowych w Ministerstwie Finansów, e-mail: anna.bartosiak3@mf.gov.pl

1 Niniejszy tekst stanowi prywatną opinię autorów i nie jest jednoznaczny z oficjalnym stanowiskiem Ministerstwa Finansów. 
1. Pojęcie staŁego miejsca prowadzenia działalności gospodarczej NA GRUNCIE PODATKU VAT W PRAWIE UE I ORZECZNICTWIE TSUE

Pojęcie stałego miejsca prowadzenia działalności gospodarczej na gruncie podatku VAT oraz zakładu na gruncie podatków dochodowych (w szczególności w umowach o unikaniu podwójnego opodatkowania) służy rozgraniczeniu jurysdykcji podatkowych poszczególnych państw - prawidłowemu alokowaniu władztwa podatkowego. W podatku VAT stałe miejsce prowadzenia działalności gospodarczej służy przede wszystkim ustaleniu miejsca świadczenia usług (zwłaszcza art. 44 i 45 Dyrektywy 2006/112²). Występowanie stałego miejsca prowadzenia działalności gospodarczej jest także kluczowe dla celów zwrotu podatku naliczonego w rozumieniu art. 171 Dyrektywy 2006/112 czy zastosowania odwrotnego obciążenia.

Pojęcie stałego miejsca prowadzenia działalności gospodarczej wprowadzono na gruncie VI Dyrektywy ${ }^{3}$, przy czym podkreślić należy, że w anglojęzycznej wersji aktu użyto pojęcia fixed establishment zamiast powszechnie używanego w kontekście podatków dochodowych sformułowania permanent establishment ${ }^{4}$. Różną nazwę tej samej instytucji na gruncie podatku dochodowego i podatku od wartości dodanej tłumaczy się chęcią rozgraniczenia zakresów stosowania ich definicji przez prawodawcę. Tezę tę potwierdza Trybunał Sprawiedliwości Unii Europejskiej (TSUE), podkreślając w swoim orzecznictwie, że pojęcie zakładu (permanent establishment) na gruncie UM-OECD jest nieistotne dla interpretacji stałego miejsca prowadzenia działalności (fixed establishment) w rozumieniu Dyrektywy 2006/1125.

2 Dyrektywa Rady 2006/112/WE z dnia 28 listopada 2006 r. w sprawie wspólnego systemu podatku od wartości dodanej (Dz.Urz. UE L 347 z dnia 11 grudnia 2006 r. ze zm., s. 1).

3 Szósta Dyrektywa Rady 77/388/EWG z dnia 17 maja 1977 r. w sprawie harmonizacji przepisów Państw Członkowskich w odniesieniu do podatków obrotowych - wspólny system podatku od wartości dodanej: ujednolicona podstawa wymiaru podatku (Dz.Urz. UE L 145 z dnia 13 czerwca 1977 r., s. 1).

4 P. Pistone, Fixed Establishment and Permanent Establishment, „International VAT Monitor” 1999, nr 3, s. 101-102. Szerzej na temat różnic terminologicznych w poszczególnych krajach zob. A. Rutkowska-Brdulak, Stałe miejsce prowadzenia działalności w VAT a podmiotowość prawnopodatkowa. Dylematy, konsekwencje, ryzyka, LEX/el. 2018. Autorka wskazuje, że w przeważającej części krajów UE pojęcie stałego miejsca prowadzenia działalności zawarte w oficjalnych tłumaczeniach przepisów dyrektyw i w krajowych regulacjach dotyczących podatku od wartości dodanej zostało wyrażone tym samym terminem, który jest używany do określenia zakładu w Konwencji Modelowej OECD oraz w umowach o unikaniu podwójnego opodatkowania.

5 Wyrok TSUE z dnia 23 marca 2006 r. w sprawie C-210/04 Ministero dell'Economia e delle Finanze i Agenzia delle Entrate przeciwko FCE Bank plc, EU:C:2006:196, gdzie Sąd 
W 2011 r. rozporządzenie wykonawcze do Dyrektywy 2006/112 (Rozporządzenie $282 / 2011^{6}$ ) wprowadziło definicję stałego miejsca prowadzenia działalności gospodarczej, będącą w istocie implementacją tez TSUE sformułowanych m.in. w sprawach Planzer ${ }^{7}$ i Berkholz ${ }^{8}$.

W Rozporządzeniu 282/2011 wprowadzono dwie definicje stałego miejsca prowadzenia działalności. Pierwsza z wprowadzonych definicji dotyczy sytuacji, gdy o miejscu świadczenia decyduje stałe miejsce prowadzenia działalności nabywcy (relacja B2B). Druga definicja znajdzie zastosowanie w przypadku, gdy o miejscu świadczenia decyduje stałe miejsce prowadzenia działalności przez świadczącego usługę (relacja B2C). Zostały one ujęte w art. 11 Rozporządzenia 282/2011. Ponadto w art. 192a Dyrektywy 2006/112 ujęto zasady przypisywania dostawy towarów i usług do stałego miejsca prowadzenia działalności gospodarczej ${ }^{9}$.

Zgodnie z art. 11 ust. 1 Rozporządzenia 282/2011 (relacja B2B): „Na użytek stosowania art. 44 Dyrektywy 2006/112/WE «stałe miejsce prowadzenia działalności gospodarczej» oznacza dowolne miejsce - inne niż miejsce siedziby działalności gospodarczej podatnika, o którym mowa w art. 10 niniejszego rozporządzenia - które charakteryzuje się wystarczającą stałością oraz odpowiednią strukturą w zakresie zaplecza personalnego i technicznego, by umożliwić przedsiębiorcy odbiór i wykorzystywanie usług świadczonych na jego rzecz do realizacji potrzeb własnych podatnika lub jego stałego miejsca prowadzenia działalności gospodarczej” ${ }^{10}$. Istotne

w pkt 39 orzekł: „Jeśli chodzi o konwencję OECD, to należy stwierdzić, że jest ona pozbawiona znaczenia dla niniejszej sprawy, skoro dotyczy podatków bezpośrednich, gdy tymczasem podatek VAT należy do podatków pośrednich”.

${ }^{6}$ Rozporządzenie Wykonawcze Rady (UE) nr 282/2011 z dnia 15 marca 2011 r. ustanawiające środki wykonawcze do dyrektywy 2006/112/WE w sprawie wspólnego systemu podatku od wartości dodanej (wersja przekształcona) (Dz.Urz. UE L 77 z dnia 23 marca 2011 r., s. 1).

7 Wyrok TSUE z dnia 28 czerwca 2007 r. w sprawie C-73/06 Planzer Luxembourg Sàrl przeciwko Bundeszentralamt für Steuern, EU:C:2007:397.

${ }^{8}$ Wyrok TSUE z dnia 4 lipca 1985 r. w sprawie 168/84 Gunter Berkholz przeciwko Finanzamt Hamburg-Mitte-Altstadt, EU:C:1985:299. Szerzej na temat podobieństw i różnic na gruncie podatków dochodowych (UM-OECD) a VAT zob. K. Spies, Permanent Establishment versus Fixed Establishment: The Same or Different?, „Bulletin for International Taxation" 2017, nr 12, s. 707.

9 P. Skorupa, K. Wróblewska, Stałe miejsce prowadzenia działalności gospodarczej a VAT - uwagi na tle przepisów rozporządzenia Rady (UE) Nr 282/2011 oraz orzecznictwa TSUE (1), „Przegląd Podatkowy” 2013, nr 7, s. 24-25.

10 Stosownie zaś do ust. 3 art. 11 Rozporządzenia 282/2011: „Fakt posiadania numeru identyfikacyjnego VAT sam w sobie nie jest wystarczający, by uznać, że podatnik posiada stałe miejsce prowadzenia działalności gospodarczej”. 
jest zatem, aby placówka nabywająca usługi (znajdująca się w innym państwie niż siedziba przedsiębiorcy) w istocie była w stanie wykorzystać i spożytkować usługi, które nabyła. Muszą być one świadczone dla jej potrzeb $^{11}$.

Powyższa definicja kładzie nacisk na możliwość nabywania i wykorzystywania usług przez stałe miejsce prowadzenia działalności gospodarczej (zdolność do konsumpcji), podczas gdy druga definicja (art. 11 ust. 2 Rozporządzenia 282/2011) odnosi się do zdolności do świadczenia usług przez stałe miejsce prowadzenia działalności gospodarczej (relacja B2C). W świetle art. 11 ust. 2 Rozporządzenia 282/2011: „Na użytek stosowania następujących artykułów «stałe miejsce prowadzenia działalności gospodarczej» oznacza dowolne miejsce - inne niż miejsce siedziby działalności gospodarczej podatnika, o którym mowa w art. 10 niniejszego rozporządzenia - które charakteryzuje się wystarczającą stałością oraz odpowiednią strukturą w zakresie zaplecza personalnego i technicznego, by umożliwić mu świadczenie usług, które wykonuje”. Różnice w tych definicjach są uzasadnione odmiennymi zasadami określania miejsca świadczenia usług w przypadku transakcji między podatnikami VAT (B2B) oraz między podatnikami VAT a konsumentami (B2C) ${ }^{12}$.

$\mathrm{W}$ literaturze przedmiotu panuje przekonanie, że definicja $\mathrm{z}$ art. 11 Rozporządzenia 282/2011 jest licha (frail) i wymaga doprecyzowania. Obserwuje się zróżnicowaną wykładnię pojęcia stałego miejsca prowadzenia działalności w orzecznictwie sądów państw Unii Europejskiej (UE), co może prowadzić do podwójnego opodatkowania względnie podwójnego nieopodatkowania spornych transakcji ${ }^{13}$. Ze względu na niedostatki prawa unijnego pole do odpowiedzi na wątpliwości i rozbieżności wynikające z nieprecyzyjnej definicji pojęcia stałego miejsca prowadzenia działalności gospodarczej powinno stanowić orzecznictwo TSUE. Szansą na to był wyrok TSUE w sprawie Welmory ${ }^{14}$.

11 A. Bartosiewicz, Nowe unijne rozporządzenie wykonawcze VAT, „Przegląd Podatkowy" 2011, nr 7, s. 14.

12 P. Skorupa, K. Wróblewska, op. cit., s. 25.

13 A. Tsielepis, The Devil Is in the Detail: An Analysis of the ECJ's Attributes to the Fixed Establishment Concept, „International VAT Monitor” 2017, nr 3, s. 215.

14 Wyrok TSUE z dnia 16 października 2014 r. w sprawie C-605/12 Welmory sp. z o.o. przeciwko Dyrektorowi Izby Skarbowej w Gdańsku, EU:C:2014:2298. 
W 2012 r. Naczelny Sąd Administracyjny zwrócił się do Trybunału Sprawiedliwości Unii Europejskiej z pytaniem prejudycjalnym dotyczącym ustalenia, czy spółka zagraniczna ma stałe miejsce prowadzenia działalności w kraju, gdy do prowadzenia swojej działalności wykorzystuje infrastrukturę udostępnioną przez spółkę krajową.

W przedstawionym w sprawie stanie faktycznym cypryjska spółka Welmory Ltd zawarła umowę o współpracę z polską spółką Welmory sp. z o.o. Spółka cypryjska zobowiązała się świadczyć na rzecz polskiej spółki usługę udostępniania internetowej strony aukcyjnej oraz usługi towarzyszące związane z dzierżawą serwerów i wystawianiem produktów na aukcjach. Spółka polska miała sprzedawać towary za pośrednictwem udostępnionej jej strony.

Sprzedaż za pośrednictwem strony aukcyjnej odbywa się dwuetapowo. Najpierw klient nabywa od spółki cypryjskiej tzw. „bidy”, czyli jednostki umożliwiające składanie ofert podczas licytacji towarów na aukcjach. Po złożeniu najwyższej oferty (wygraniu aukcji) klient nabywa wylicytowany towar od spółki polskiej.

Spółka polska otrzymywała od spółki cypryjskiej udział w przychodach ze sprzedaży „bidów” kupowanych przez polskich klientów oraz wynagrodzenie za usługi reklamy, obsługi, dostarczania informacji i przetwarzania danych świadczone na rzecz spółki cypryjskiej.

Zdaniem Dyrektora Izby Skarbowej w Gdańsku usługi świadczone przez polską spółkę na rzecz spółki cypryjskiej powinny podlegać opodatkowaniu podatkiem od towarów i usług na terytorium Rzeczypospolitej Polskiej, a nie Republiki Cypryjskiej. Poprzez korzystanie z zaplecza personalnego i technicznego spółki polskiej spółka cypryjska ma bowiem na terytorium Polski stałe miejsce prowadzenia działalności. Stanowisko to potwierdził Wojewódzki Sąd Administracyjny. Ze względu na wątpliwości interpretacyjne sprawa została skierowana przez NSA do TSUE.

W odpowiedzi na pytanie prejudycjalne TSUE orzekł, że „Pierwszy podatnik mający siedzibę działalności gospodarczej w jednym państwie członkowskim, który korzysta z usług świadczonych przez drugiego podatnika mającego siedzibę $\mathrm{w}$ innym państwie członkowskim, powinien być uważany za posiadającego w tym innym państwie członkowskim stałe miejsce prowadzenia działalności w rozumieniu art. 44 dyrektywy [...], w celu określenia miejsca opodatkowania tych usług, jeżeli to stałe miejsce 
charakteryzuje się wystarczającą stałością oraz odpowiednią strukturą w zakresie zaplecza personalnego i technicznego, by umożliwić mu odbiór usług i wykorzystywanie ich do celów jego działalności gospodarczej, czego zbadanie należy do sądu odsyłającego" 15 .

Należy stwierdzić, że wypowiedź Trybunału nie precyzuje pojęcia stałego miejsca prowadzenia działalności gospodarczej, a „odesłanie” do sądu krajowego przenosi cały ciężar argumentacyjny na dany sąd krajowy (w tym przypadku NSA), którego to wykładnia nie będzie miała waloru „precedensowego" jak orzecznictwo TSUE. Jednocześnie jednak TSUE pozostawia w ten sposób otwarte pole do liberalnej wykładni omawianego przepisu, pozwalając sądowi krajowemu na samodzielną ocenę tego, czy charakteryzujący dany przypadek zakres zaplecza personalnego i technicznego jest wystarczający dla rozpoznania w danym kraju stałego miejsca prowadzenia działalności.

W sprawie Welmory TSUE pozostawił otwartą kwestię, czy podatnik dysponuje w państwie UE stałym miejscem prowadzenia działalności gospodarczej, jeśli inny podmiot przekazał/udostępnił mu zasoby personalne i techniczne, którymi może on faktycznie dysponować jak właściciel ${ }^{16}$.

Wyrok TSUE nie wprowadził zatem nowych, precyzyjnych kryteriów identyfikacji stałego miejsca prowadzenia działalności. Nie przyczynił się do ujednolicenia wykładni prawa i jako taki oceniany jest w niemieckiej literaturze przedmiotu jako niezadowalający ${ }^{17}$.

\section{PojęCie staŁego miejsca PROWAdZENia dZiaŁAlności GOSPODARCZEJ W NIEMIECKIM PRAWIE PODATKOWYM}

Niemiecka ustawa o podatku od towarów i usług (ustawa o podatku obrotowym, Umsatzsteuergesetz, dalej: $\mathrm{UStG}^{18}$ ) nie zawiera definicji stałego miejsca prowadzenia działalności gospodarczej.

15 Wyrok TSUE z dnia 16 października 2014 r., Welmory, C-605/12, EU:C:2014:2298, pkt 65.

16 H.M. Grambeck, UStG $\$ 3$ a Ort der sonstigen Leistung, [w:] Beck'scher Online-Kommentar Umsatzsteuergesetz 2020, Hrsg. R. Weymüller, München 2020, Rn. 56.

17 B. Monfort, EuGH: Begriff der festen Niederlassung des Empfängers einer Dienstleistung - Welmory, MwStR 2014, s. 541.

${ }_{18}$ Umsatzsteuergesetz in der Fassung der Bekanntmachung vom 21. Februar 2005 (BGBl. I S. 386), das zuletzt durch Artikel 3 des Gesetzes vom 21. Dezember 2019 (BGBl. I S. 2886) geändert worden ist. 
$\mathrm{Na}$ gruncie prawa niemieckiego stałe miejsce prowadzenia działalności gospodarczej może być określane zamiennie dwoma terminami: feste Niederlassung lub Betriebsstätte (obydwa pojęcia tłumaczy się często jako „stały zakład” lub „zakład”) ${ }^{19}$. Pojęcie feste Niederlassung pochodzi z prawodawstwa Unii Europejskiej (takiego sformułowania użyto w niemieckojęzycznej wersji art. 11 Rozporządzenia 282/2011), natomiast termin Betriebsstätte (zakład) używany jest w niemieckim prawie krajowym.

$\mathrm{W}$ niemieckim prawie podatkowym pojęcie Betriebsstätte definiowane jest w $\$ 12$ niemieckiej ordynacji podatkowej (Abgabenordnung, dalej: $\left.\mathrm{AO}^{20}\right)$. Zgodnie z $\$ 12$ AO zakładem jest „każde stałe miejsce prowadzenia działalności (feste Geschäftseinrichtung) lub instalacja (Anlage) służące działalności przedsiębiorstwa" ${ }^{21}$. W ustępie drugim wymienione są przykładowe formy stanowiące zakład (Betriebsstätte), tj. miejsce siedziby zarządu, oddział, miejsce prowadzenia interesów, warsztat, magazyn i inne.

Termin Betriebsstätte ma bardzo duże znaczenie praktyczne. Stanowi „podatkowo istotny punkt zaczepienia”, na podstawie którego określa się obowiązek podatkowy w przypadku wielu danin publicznych ${ }^{22}$. Pozwala na stwierdzenie, czy podmiot zagraniczny podlega ograniczonemu obowiązkowi podatkowemu w Niemczech ( $\$ 49$ ust. $1 \mathrm{nr} 2$ a niemieckiej ustawy o podatku dochodowym od osób fizycznych, Einkommensteuergesetz, $\mathrm{EStG}^{23}$ ), czy też dla zastosowania konsekwencji exit tax na gruncie niemieckiej ustawy o podatku dochodowym od osób prawnych $(\$ 12 \text { Körperschaftsteuergesetz KStG })^{24}$. Konstrukcja zakładu pozwala także

19 FG Schleswig-Holstein, wyrok z dnia 17 maja 2018 r., 4 K 47/17, pkt 34, EFG 2018, 1500.

20 Abgabenordnung in der Fassung der Bekanntmachung vom 1. Oktober 2002 (BGBl. I S. 3866; 2003 I S. 61), die zuletzt durch Artikel 1 des Gesetzes vom 21. Dezember 2019 (BGBl. I S. 2875) geändert worden ist.

${ }^{21} \$ 12$ ust. 1 AO. Oficjalne tłumaczenie sporządzone przez służby językowe Federalnego Ministerstwa Finansów brzmi następująco: „Permanent establishment shall mean any fixed place of business or facility serving the business of an enterprises”.

22 E.M. Gersch, § 12 AO, [w:] Abgabenordnung (AO). Kommentar, Hrsg. F. Klein, München 2018, Rn. 1.

${ }^{23}$ Einkommensteuergesetz in der Fassung der Bekanntmachung vom 8. Oktober 2009 (BGBl. I S. 3366, 3862), das zuletzt durch Artikel 2 des Gesetzes vom 21. Dezember 2019 (BGBl. I S. 2886) geändert worden ist.

24 Körperschaftsteuergesetz in der Fassung der Bekanntmachung vom 15. Oktober 2002 (BGBl. I S. 4144), das zuletzt durch Artikel 6 des Gesetzes vom 21. Dezember 2019 (BGBl. I S. 2875) geändert worden ist. 
na przypisanie podmiotów krajowych do określonych jednostek terytorialnych, m.in. w celu prawidłowego określenia i odprowadzenia niektórych podatków lokalnych (np. $\$ \$ 4,28$ ustawy o podatku od działalności gospodarczej - Gewerbesteuergesetz, GewStG $\left.{ }^{25}\right)^{26}$.

Niemiecka UStG posługuje się pojęciem Betriebsstätte przede wszystkim dla celów ustalenia miejsca świadczenia usług ( $\$ 3$ a UStG) czy odwrotnego obciążenia ( $\$ 13 \mathrm{~b}$ UStG). Podobnie jak na gruncie prawa UE, w Niemczech podkreśla się, że w rodzimym podatku VAT pojęciu temu należy nadać autonomiczne znaczenie i dokonywać jego wykładni niezależnie od regulacji i orzecznictwa dotyczących innych danin, natomiast ze szczególnym uwzględnieniem dedykowanego podatkowi od wartości dodanej prawa UE i orzecznictwa TSUE ${ }^{27}$.

\section{WykŁadnia Federalnego Ministerstwa Finansów}

Źródłem wiedzy dla podatników na temat sposobu wykładni pojęcia stałego miejsca prowadzenia działalności gospodarczej przez administrację podatkową są interpretacje ${ }^{28}$ Federalnego Ministerstwa Finansów (Bundesfinanzministerium, dalej: BMF). Dla ustalenia, czy występuje stałe miejsce prowadzenia działalności, niemiecka administracja przyjmuje kryteria pochodzące z orzecznictwa TSUE. Odnosi się do nich zwłaszcza przy określaniu miejsca świadczenia usług - $\$ 3$ a UStG. Zarówno BMF, jak i literatura oraz orzecznictwo wskazują na następujące kryteria: (1) minimalne zaplecze personalne i techniczne (kryterium ilościowe i jakościowe); (2) wystarczająca stałość oraz odpowiednia struktura (kryterium czasowe

${ }^{25}$ Gewerbesteuergesetz in der Fassung der Bekanntmachung vom 15. Oktober 2002 (BGBl. I S. 4167), das zuletzt durch Artikel 9 des Gesetzes vom 12. Dezember 2019 (BGBl. I S. 2451) geändert worden ist. Gewerbesteuer jest podatkiem dochodowym obciążającym działalność gospodarczą, pobieranym niezależnie od ESt oraz KSt. Podatek od działalności gospodarczej w Niemczech jest pobierany przez gminy, dla których stanowi najważniejsze źródło dochodów.

${ }^{26}$ U. Koenig, § 12 AO, [w:] Abgabenordnung (AO). Kommentar, Hrsg. U. Koenig, München 2014, Rn. 1.

27 E. Haller, Feste Niederlassung - alle Klarheiten beseitigt?, MwStR 2017, s. 650.

${ }_{28}$ Umsatzsteuer-Anwendungserlass (UStAE) vom 1. Oktober 2010, BStBl I S. 846 - aktuelle Version (Stand 6. Februar 2020) - nach dem Stand zum 31. Dezember 2019, https://www.bundesfinanzministerium.de/Web/DE/Themen/Steuern/Steuerarten/Umsatzsteuer/Umsatzsteuer_Anwendungserlass/umsatzsteuer_anwendungserlass.html (dostęp: 30.03.2020). 
i przestrzenne); (3) niesamodzielność (brak odrębności prawnej lub gospodarczej) oraz (4) możliwość autonomicznego świadczenia usług/nabywania usług na własne potrzeby (tzw. aktywne i pasywne stałe miejsce prowadzenia działalności gospodarczej).

BMF przyjmuje, że stabilna struktura charakterystyczna dla stałego miejsca prowadzenia działalności występuje przykładowo, jeśli jednostka dysponuje wystarczającą liczbą pracowników, aby samodzielnie zawierać umowy, prowadzić księgowość i podejmować decyzje gospodarcze, np. w sprawie zakupu towarów. Zakładem może być także spółka zależna (Organgesellschaft) w ramach grupy VAT w Niemczech ${ }^{29}$. Co ciekawe, stałe miejsce prowadzenia działalności gospodarczej może powstać także na pokładzie statku (np. zakład fryzjerski, salon masażu).

\section{ORZECZNICTWO NIEMIECKICH SĄDÓW FINANSOWYCH} - SPORY O ZAKRES DEFINICJI

Koncepcja stałego miejsca prowadzenia działalności gospodarczej dla celów niemieckiego podatku VAT dookreślana jest w orzecznictwie krajowych sądów finansowych ${ }^{30}$ (sąd finansowy - Finanzgericht, dalej: FG). To właśnie analiza orzecznictwa pozwala na uchwycenie istoty pojęcia stałego miejsca prowadzenia działalności gospodarczej na gruncie niemieckiego podatku VAT.

Zakres stałego miejsca prowadzenia działalności gospodarczej był i jest sporny zwłaszcza w aspekcie:

1) konieczności i zakresu dysponowania przez podatnika własnym personelem $^{31}$;

2) zakresu kontroli nad zasobami personalnymi i technicznymi.

${ }^{29}$ W Niemczech funkcjonują grupy VAT. Pomiędzy podmiotami należącymi do grupy obroty są neutralne dla celów VAT $-\S 2$ UStG.

${ }^{30} \mathrm{~W}$ Niemczech właściwe w sprawach podatkowych są sądy finansowe.

31 W Polsce niedawno w tym kontekście NSA podkreślił: „Wskazać należy, że nie jest konieczne, aby personel wykorzystywany w stałym miejscu prowadzenia działalności stanowili pracownicy danego podatnika, gdyż mogą być to także pracownicy podmiotu trzeciego, działającego na rzecz danego podatnika. Również środki techniczne, składające się na zaplecze techniczne, nie muszą być własnością podatnika, ale istotnym jest, aby miał on nad nim władztwo, aby mógł je wykorzystywać przy świadczeniu usług" (wyrok NSA z dnia 31 października 2019 r., I FSK 1143/17, http://orzeczenia.nsa.gov.pl/ doc/2018133D96). 
Powyższe zagadnienia były przedmiotem szczegółowej analizy ze strony niemieckiego orzecznictwa w postępowaniach dotyczących kolejno:

1) przedsiębiorców prowadzących na terenie Niemiec farmy wiatrowe;

2) podatników najmujących magazyny/wykorzystujących powierzchnie biurowe.

\subsection{Własne zaplecze personalne - turbiny wiatrowe}

Niemieckie sądy finansowe wielokrotnie wypowiadały się na temat zastosowania kryterium minimalnego zaplecza personalnego i technicznego w stosunku do operatorów turbin wiatrowych.

W wyroku FG Münster (wyrok z dnia 5 września 2013 r., 5 K 1768/10²) sąd stanął na stanowisku, że można mówić o stałym miejscu prowadzenia działalności nawet wtedy, gdy podmiot nie zatrudnia własnego personelu, pod warunkiem że jego szerokie zasoby techniczne kompensują brak zasobów ludzkich.

Sąd w Münster po przeanalizowaniu orzecznictwa TSUE podkreślił, że turbiny wiatrowe podatnika są stałą instalacją o wysokiej wartości, która charakteryzuje się najwyższym stopniem stałości. W świetle przedstawionych okoliczności brak własnego personelu, który stale na miejscu obsługiwałby turbiny, nie stanowi przeszkody do przyjęcia, że spółka posiada stałe miejsce prowadzenia działalności w Niemczech.

Posiadanie zasobów ludzkich - co podkreślił Sąd - jest ważnym kryterium dla określenia, czy istnieje stałe miejsce prowadzenia działalności, jednakże nie znaczy to, że kryteria posiadania zasobów ludzkich i technicznych muszą być spełnione w równym stopniu. Ponadprzeciętnie rozbudowane zasoby techniczne mogą kompensować niewielkie zasoby ludzkie, a w wyjątkowych przypadkach także ich brak. Fakt, że prowadzenie spraw spółki oraz konserwacja urządzeń (funkcje pomocnicze) wykonywane są przez podmioty zewnętrzne, a nie przez własny personel, nie stanowi przeszkody do przyjęcia, że spółka posiada stałe miejsce prowadzenia działalności w Niemczech. Sąd podkreślił, że taką wykładnię uzasadnia też fakt, iż dostawa prądu jako taka odbywać się może bez bezpośredniej obsługi klienta ze strony personelu.

Orzeczenie niemieckiego sądu stanowi twórcze rozwinięcie regulacji unijnej. Pomimo uzasadnionych wątpliwości dotyczących jego zgodności

\footnotetext{
32 Wyrok FG Münster z dnia 5 września 2013 r., 5 K 1768/10, EFG 2013, 1890.
} 
z prawem UE, wyrok FG Münster spotkał się z przychylnym przyjęciem ze strony przynajmniej części niemieckiej literatury przedmiotu ${ }^{33}$. Podkreśla się, że identyfikacja stałego miejsca prowadzenia działalności przy braku posiadania własnego personelu (jeżeli świadczenie usługi jest możliwe również bez niego) mogłaby znaleźć zastosowanie w licznych sytuacjach gospodarczych o niejednoznacznej kwalifikacji podatkowej. Podobną argumentację można by zastosować m.in. w stosunku do prowadzenia serwerowni, w której serwery udostępnia się (wynajmuje) klientom, a także w przypadku wszelkich rodzajów sieci przesyłowych, do których odpłatnie udostępnia się prawo użytkowania ${ }^{34}$. W literaturze niemieckiej dominuje jednak pogląd, że sam serwer internetowy nie stanowi zakładu ${ }^{35}$.

Stanowisko prezentowane przez FG Münster podtrzymał, również w kontekście turbin wiatrowych, FG Köln (wyrok z dnia 14 marca 2017 r.,

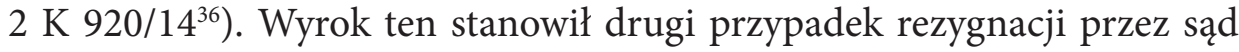
z zastosowania kryterium minimalnego zaplecza personalnego przy identyfikacji stałego miejsca prowadzenia działalności, tzn. interpretacji wykraczającej poza ramy Rozporządzenia 282/2011 oraz wykładni stosowanej przez BMF (Abschn. 3a. 1 Abs. 3 S. 2 UStAE - zaplecze personalne i techniczne). Trudno jednak mówić o możliwości zastosowania tej interpretacji w przypadkach innych niż analizowane przez sądy. W literaturze podkreśla się, że odstępstwo ma dotychczas charakter punktowy. Prezentowana linia orzecznicza dotyczy jednego, konkretnego rodzaju działalności gospodarczej, co nie pozwala na wysunięcie tezy, jakoby rezygnacja z kryterium minimalnego zaplecza personalnego miała charakter generalny, wykraczający poza przypadek elektrowni wiatrowych ${ }^{37}$.

33 A. Pogodda, Zur Frage, ob das bloße Unterhalten von Windkrafträdern im Inland eine Zweigniederlassung i. S. von § UStG $\$ 13 b$ Abs. UStG $\$ 13 B$ Absatz4 UStG a. F. begründet, MwStR 2014, s. 35.

${ }^{34}$ Co ciekawe, w tym kontekście podkreśla się także, że BMF uznaje, iż podatnik ma siedzibę na terytorium Niemiec, jeśli posiada nieruchomość położoną w Niemczech, którą wynajmuje na cele czynności opodatkowanych (Abschn. 13b. 11. Abs. 2 Satz 2 UStAE). Nie jest to jednak bezsporne w kontekście wyroku Bundesfinanzhof (BFH) z dnia 9 maja 2017 r., XI B 13/17, BFH/NV 2017, 1198.

${ }_{35}$ H.M. Grambeck, UStG $\$ 3 a$ Ort der sonstigen Leistung, [w:] R. Weymüller (Hrsg.), Beck'scher Online-Kommentar Umsatzsteuergesetz 2018, München 2018, Rn. 56.

${ }^{36}$ Wyrok FG Köln z dnia 14 marca 2017 r., 2 K 920/14, BB 2017, 2006.

37 O. Lembke, Durch das Unterhalten von Windrädern wird eine inländische Betriebsstätte begründet, MwStR 2017, s. 889. 
Ostrożne podejście do występowania kryteriów stałego miejsca prowadzenia działalności gospodarczej podzielił FG Schleswig-Holstein (wyrok

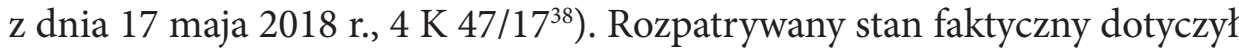
duńskiej spółki osobowej posiadającej w Niemczech elektrownie wiatrowe. Za obsługę księgową i kontakty $\mathrm{z}$ klientem odpowiadała mieszcząca się w Danii centrala firmy, bieżąca obsługa wiatraków (konserwacja i naprawy) zlecone zaś zostały podmiotowi trzeciemu - niemieckiej spółce kapitałowej.

W orzeczeniu sąd uznał, że zlecenie na zewnątrz prac konserwacyjnych, a także usług księgowych oraz płatniczych nie przeszkadza w przyjęciu występowania w Niemczech stałego miejsca prowadzenia działalności gospodarczej (są to obroty uboczne - tu powołanie się na wyrok TSUE w sprawie Planzer). Przyjęciu stałego miejsca prowadzenia działalności gospodarczej nie stoi na przeszkodzie - w opinii Sądu - również to, że skarżąca spółka nie dysponowała w Niemczech żadnym biurem, w którym pracownicy zawieraliby umowy na dostawy prądu. Uzasadniał to fakt, iż spółka zawarła długotrwałą umowę z wyłącznym odbiorcą na dostawy prądu, stąd zawieranie bieżących umów było zbędne.

Co istotne, w orzeczeniu sąd potwierdził istnienie stałego miejsca prowadzenia działalności gospodarczej, nie powołując się na tezę o pełnym kompensowaniu zasobów ludzkich przez rozbudowane zasoby techniczne. Zamiast tego uznał za wystarczające dla identyfikacji stałego miejsca prowadzenia działalności zaangażowanie przez przedsiębiorcę niewielkich zasobów ludzkich również w sytuacji, gdy nie należą one do zasobów własnych przedsiębiorstwa (pracownicy nie są bezpośrednio zatrudnieni przez podatnika/przedsiębiorcę). Sąd podkreślił, że za zasoby ludzkie można uznać też personel podwykonawcy ${ }^{39}$ zajmującego się prowadzeniem działalności operacyjnej (kierownictwem operacyjnym) na zlecenie operatora (tu: nadzorem nad pracą turbin).

Sąd podkreślił także, że nie widzi podstaw do zadania pytania prejudycjalnego do TSUE, gdyż zgodnie z wyrokiem w sprawie Welmory kwestia ustalenia, czy w danej sprawie występuje stałe miejsce prowadzenia działalności (feste Niederlassung) cechujące się wystarczającym zapleczem personalnym i technicznym, należy do wyłącznej kompetencji sądu krajowego ${ }^{40}$.

38 Wyrok FG Schleswig-Holstein z dnia 17 maja 2018 r., 4 K 47/17, pkt 54, EFG 2018, 1500.

$39 \mathrm{~W}$ tym przypadku można uznać, że personel podwykonawcy, mimo że prawnie jest przypisany do podwykonawcy, gospodarczo może być przypisany (wirtschaftliche Zurechnung) do instalacji operatora (zleceniodawcy), tj. de facto działa na rzecz zleceniodawcy.

${ }^{40}$ Wyrok FG Schleswig-Holstein z dnia 17 maja 2018 r., 4 K 47/17, pkt 54, EFG 2018, 1500. Od wyroku FG Schleswig-Holstein z dnia 17 maja 2018 r., 4 K 47/17, została złożona 
5.2. Kryterium sprawowania kontroli nad zapleczem personalnym i technicznym - powierzchnie biurowe/magazynowe

W dotychczasowej linii orzeczniczej (m.in. FG Köln w wyroku

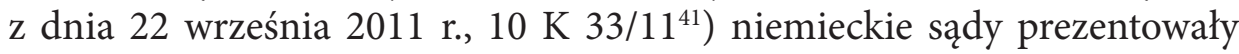
pogląd, że można przyjąć istnienie stałego miejsca prowadzenia działalności w sytuacji, gdy przedsiębiorca ma faktyczną możliwość dysponowania znajdującymi się na terytorium Niemiec pomieszczeniami, personelem oraz wyposażeniem - nawet gdy brak ku temu podstawy prawnej. Stanowisko to uległo zmianie po wyroku TSUE w sprawie Welmory C-605/12 ${ }^{42}$. Według jego sentencji przedsiębiorca nie musi być bowiem właścicielem zasobów ludzkich oraz technicznych, ale musi istnieć podstawa prawna (umowa), która daje mu możliwość dysponowania nimi jak właściciel. Ponadto taka umowa powinna zawierać zapisy uniemożliwiające jej nagłe rozwiązanie (tak też BFH w uchwale z 15 lutego 2017 r., XI R 21/15 $5^{43}$ ). W świetle wyroku TSUE zwykłe używanie zasobów nie daje prawa do rozporządzania nimi jak właściciel, a zatem nie stanowi przesłanki do stwierdzenia istnienia stałego miejsca prowadzenia działalności ${ }^{44}$.

Niewiele później w podobny sposób w wyroku z dnia 16 października 2012 r., 8 K 2753/0845, orzekł FG Köln, który odnosząc się do kwestii dysponowania zasobami personalnymi i technicznymi, stwierdził, że nie można mówić o stałym miejscu prowadzenia działalności zagranicznego podmiotu, jeżeli ten zagraniczny podmiot jest uprawniony do używania pomieszczeń krajowego podmiotu za jego zgodą i tylko w jego godzinach pracy, pomiędzy podmiotami nie istnieje umowa najmu, a zagraniczny podmiot nie posiada własnych kluczy do pomieszczeń krajowego podmiotu ani urządzonego w nich stanowiska pracy.

rewizja do BFH. BFH w wyroku z dnia 12 grudnia 2019 r., V R 20/18, uchylił wyrok FG Schleswig-Holstein, jednakże z innych przyczyn niż pytanie dotyczące kryteriów przyjęcia stałego miejsca prowadzenia działalności. BFH w żaden sposób nie odniósł się do rozumowania sądu pierwszej instancji w zakresie przesłanek pozwalających na stwierdzenie występowania stałego miejsca prowadzenia działalności. Pozostaje zatem nierozstrzygnięte, czy linia argumentacyjna sądu pierwszej instancji była słuszna.

41 Wyrok FG Köln z dnia 22 września 2011 r., 10 K 33/11, EFG 2012, 768 (dostęp: 30.03.2020).

${ }^{42}$ Ch. Korn, § 3a UStG, [w:] Umsatzsteuergesetz. Kommentar (18. Auflage), Hrsg. J. Bunjes, München 2018, UStG $₫ 3 a, R n .14 a$.

${ }^{43}$ Zob. https://datenbank.nwb.de/Dokument/Anzeigen/692404/.

${ }^{44}$ Ch. Korn, op. cit., Rn. 14a. 
Zakres i podstawa prawna kontroli nad znajdującymi się w Niemczech zasobami i infrastrukturą były także sporne w przypadku powierzchni magazynowanych najmowanych na terytorium Niemiec. FG München w wyroku z dnia 27 listopada 2008 r., $14 \mathrm{~K} 3837 / 06^{45}$, orzekł, że magazyn nie stanowi stałego miejsca prowadzenia działalności zagranicznego przedsiębiorstwa, jeśli wykonywane są w nim tylko czynności przygotowawcze i pomocnicze, a działający w nim personel nie ma prawa do zawierania umów w imieniu spółki. Warto nadmienić, że w literaturze przedmiotu spotkać się można z polemiką dotyczącą kwestii nieuznawania magazynu za stałe miejsce prowadzenia działalności - zmiana stanowiska sądów w tym zakresie rozwiązałaby wiele niejasności dotyczących alokacji prawa do opodatkowania do poszczególnych jurysdykcji ${ }^{46}$.

6. WNIOSKI

Koncepcja stałego miejsca prowadzenia działalności gospodarczej dla celów VAT (Betriebsstätte) ulega w Niemczech ewolucji. Pomimo że od 2011 r. Rozporządzenie 282/2011 zawiera definicję stałego miejsca prowadzenia działalności gospodarczej, nie milkną spory wokół zakresu Betriebsstätte w Niemczech. Orzecznictwo TSUE daje co prawda ogólne wskazówki interpretacyjne, lecz ocenia się je - biorąc pod uwagę wyrok w sprawie Welmory - jako niewystarczające do rozwiązywania wielu problemów powstałych zwłaszcza na tle nowoczesnych sposobów dystrybucji i handlu.

Niemieckie sądy finansowe, dokonując oceny występowania stałego miejsca prowadzenia działalności gospodarczej, za punkt wyjścia słusznie przyjmują treść Rozporządzenia 282/2011 oraz orzecznictwo TSUE. Niektóre z nich posuwają się jednak do specyficznego „rozłożenia akcentów”, dokonując odważnej oceny intensywności występowania przesłanek pozwalających na stwierdzenie istnienia/nieistnienia Betriebsstätte.

Najbardziej kontrowersyjnym przykładem tej praktyki jest linia orzecznicza skutkująca uznaniem turbin wiatrowych za spełniające kryteria stałego miejsca prowadzenia działalności gospodarczej. Sądy finansowe stoją na stanowisku, że przy istotnym zaangażowaniu technicznym występowanie komponentu ludzkiego może ograniczyć się do korzystania z cudzego

45 Zob. https://datenbank.nwb.de/Dokument/Anzeigen/370829/ (dostęp: 30.03.2020).

46 S. Becker, Warenlager als umsatzsteuerliche Betriebsstätte bzw. feste Niederlassung, DStR 2015, s. 1217. 
personelu, a w szczególnych przypadkach Betriebsstätte może zaistnieć nawet bez żadnego zaplecza personalnego. Obecnie oczekuje się potwierdzenia tej linii orzeczniczej przez Federalny Sąd Finansowy.

Wydaje się, że słuszne są poglądy prezentowane w niemieckiej literaturze uznające za niezgodne $\mathrm{z}$ prawem unijnym (orzecznictwem TSUE) stanowisko, że stałe miejsce prowadzenia działalności gospodarczej dla celów VAT występować może nawet przy całkowitym braku występowania zaplecza personalnego. Wyrażony przez niektóre niemieckie sądy pogląd o subsydiarnym charakterze kryterium personalnego lub jego „rekompensowaniu” przez rozbudowaną infrastrukturę techniczną nie znajduje uzasadnienia ani na gruncie Rozporządzenia 282/211, ani w kontekście orzecznictwa TSUE.

\section{BiBLIOGRAFIA}

Bartosiewicz A., Nowe unijne rozporzadzenie wykonawcze VAT, „Przegląd Podatkowy” 2011, nr 7.

Becker S., Warenlager als umsatzsteuerliche Betriebsstätte bzw. feste Niederlassung, DStR 2015. Gersch E.M., \$12 AO, [w:] Abgabenordnung (AO). Kommentar, Hrsg. F. Klein, München 2018. Grambeck H.M., UStG $\$ 3$ a Ort der sonstigen Leistung, [w:] Beck'scher Online-Kommentar Umsatzsteuergesetz 2018, Hrsg. R. Weymüller, München 2018.

Haller E., Feste Niederlassung - alle Klarheiten beseitigt?, MwStR 2017.

Koenig U., \$1 12 AO, [w:] Abgabenordnung (AO). Kommentar, Hrsg. U. Koenig, München 2014. Korn Ch., \$ 3a UStG, [w:] Umsatzsteuergesetz. Kommentar, Hrsg. J. Bunjes, München 2018.

Lembke O., Durch das Unterhalten von Windrädern wird eine inländische Betriebsstätte begründet, MwStR 2017.

Monfort B., EuGH: Begriff der festen Niederlassung des Empfängers einer Dienstleistung - Welmory, MwStR 2014.

Pistone P., Fixed establishment and permanent establishment, „International VAT Monitor” 1999, nr 3.

Pogodda A., Zur Frage, ob das bloße Unterhalten von Windkrafträdern im Inland eine Zweigniederlassung i. S. von $₫ U S t G \$ 13 b$ Abs. USt $G \$ 13 B$ Absatz4 UStG a. F. begründet, MwStR 2014.

Rutkowska-Brdulak A., Stałe miejsce prowadzenia działalności w VAT a podmiotowość prawnopodatkowa. Dylematy, konsekwencje, ryzyka, LEX/el. 2018.

Skorupa P., Wróblewska K., Stałe miejsce prowadzenia działalności gospodarczej a VAT - uwagi na tle przepisów rozporzadzenia Rady (UE) Nr 282/2011 oraz orzecznictwa TSUE (1), „Przegląd Podatkowy” 2013, nr 7.

Spies K., Permanent establishment versus fixed establishment: The same or different?, „Bulletin for International Taxation" 2017, nr 12.

Tsielepis A., The devil is in the detail: An analysis of the ECJ's attributes to the fixed establishment concept, „International VAT Monitor” 2017, nr 3. 


\section{FiXed PlaCe of ESTABLISHMENT UNDER GeRman VAT AND TAX PRACTICE}

Summary. The aim of the study was to analyze the concept of a fixed establishment in the German VAT Act and its interpretation by the German financial courts and tax authorities. The German financial courts, when assessing the criteria for accepting the existence of a fixed establishment, are rightly referring to Regulation No. 282/2011 and the case law of the CJEU. Nevertheless, in some cases, the judiciary allows for the existence of a fixed establishment in Germany even if the taxpayer uses someone else's staff and does not even have any personnel facilities. In the opinion of the Authors, this is an interpretation that goes far beyond any justification, neither in EU law nor in the case law of the CJEU.

Keywords: fixed establishment, sufficient degree of permanence, suitable structure in terms of human and technical resources, VAT 